\title{
Structural behaviour of CFRP reinforced concrete members under monotonic and cyclic long-term loading
}

\author{
Redouan El Ghadioui (D) Dominik Hiesch • Lukas Bujotzek · Tilo Proske • \\ Carl-Alexander Graubner
}

Received: 20 January 2021 / Accepted: 23 May 2021/Published online: 23 June 2021

(C) The Author(s) 2021

\begin{abstract}
A large percentage of the damages to reinforced concrete structures is caused by corrosion of the reinforcement steel, which often leads to expensive repairs or new construction of existing structures. Due to their high strength and resistance to corrosion, reinforcements made of carbon fibre-reinforced polymers (CFRP) are becoming more and more important in structural engineering. It is expected, that the service life of CFRP reinforced concrete (RC) members can be significantly increased as the strength-reduction due to corrosion is negligible compared to conventional RC members. Therefore, precise knowledge of the long-term behaviour of CFRP RC members is required in order to ensure safe and economic design. This paper presents experimental investigations on the long-term behaviour of CFRP $\mathrm{RC}$ members as well as steel-reinforced RC members under monotonic and cyclic long-term loading with varying load levels, different cross-sectional shapes and shear slendernesses. Accompanying experiments on the concrete creep behaviour that were conducted within the investigations are shown. Within the scope of the experiments, the deflections as well as the strains on the top and bottom side of the RC members
\end{abstract}

R. El Ghadioui $(\bowtie) \cdot$ D. Hiesch · L. Bujotzek ·

T. Proske $\cdot$ C.-A. Graubner

Institute of Concrete and Masonry Structures, Technical

University of Darmstadt, Franziska-Braun-Str. 3,

64287 Darmstadt, Germany

e-mail: el-ghadioui@massivbau.tu-darmstadt.de

URL: http://www.massivbau.tu-darmstadt.de were measured using displacement sensors and strain gauges. The experimental data is evaluated, especially with regard to the time-dependent deflections. The data is compared to existing mechanical and empirical models, which are usually derived for steel-reinforced RC members. Based on the experimental data, the time-dependent reduction of stiffness and conclusions for the calculation of deflections are shown.

Keywords FRP - CFRP - RC $\cdot$ Carbon - Concrete Monotonic loading $\cdot$ Cyclic loading $\cdot$ Long-term

\section{Introduction}

Reinforced concrete (RC) is efficient, cost-effective, malleable and it has become the most important building material in terms of quantity. Despite its many advantages, there is still great potential for improvement, especially since a large part of the damages to RC structures is due to corrosion of the reinforcing steel [1].

As a result, it is often not possible to achieve the service lives assumed in the design of RC structures, so that either expensive repairs or entire replacement structures are required. In order to counteract this issue, researchers all over the globe investigate the potential of alternative reinforcement materials such as fibre-reinforced polymers (FRP) [2-10]. Carbon fibre-reinforced polymer (CFRP) reinforcement in 
particular has proven to be a reasonable alternative due to its resistance to corrosion and other chemical and physical attacks as well as its high tensile strength and relatively high modulus of elasticity compared to other fibre materials. In order to reach or even extend the planned service lives of RC structures through the use of CFRP reinforcement, precise knowledge of the behaviour of CFRP RC members under monotonic and cyclic long-term loading is required.

Within the scope of the joint research project Carbon Concrete Composite [11], structural tests under monotonic and cyclic long-term loading on RC members with different types of reinforcement (CFRP textile fabrics, CFRP bars, steel bars B500), cross-section (slabs, beams), load position and failure mode were carried out.

The material properties are determined experimentally and are used in the context of analytical investigations of long-term deflections as well as for the evaluation of the load-bearing capacity depending on effects due to permanent load. The results of the experimental investigations on the structural behaviour of the RC members under short-term loading have been reported in a previous publication [12].

\section{Test-setup and material properties}

\subsection{Test-setup}

The main parameters of the RC members tested under monotonic and cyclic long-term loading are summarised in Table 1 and Fig. 1. The mean effective depths of the specimens $d_{\mathrm{m}}$ were measured in the critical cross section. The RC members with reinforcing steel were designed in such a way that the mechanical reinforcement ratio $\omega_{\mathrm{m}}=A_{\mathrm{s} / \mathrm{f}} \cdot f_{\mathrm{tm}} /\left(b_{\mathrm{m}}\right.$ $\left.d_{\mathrm{m}} \cdot f_{\mathrm{cm}}\right)$ of the corresponding CFRP RC members is comparable. Due to the different tensile strengths of the reinforcement, the geometric reinforcement ratio $\rho_{1}=A_{\mathrm{s} / \mathrm{f}} /\left(b_{\mathrm{m}} \cdot d_{\mathrm{m}}\right)$ for the steel RC members is significantly higher compared to the CFRP RC members. The midspan deflections were measured using a wire transducer.

\subsection{Concrete}

Two different normal strength concretes (C 40/50 and C 50/60) were used for the test series $\mathrm{A}$ and $\mathrm{B}$, respectively (see also Table 1). The concrete properties were determined by experiments on cubes, cylinders and drill cores at different concrete ages and converted to the uniaxial compressive strength $f_{1, \mathrm{c}, \mathrm{m}}$ according to [13]. The ratios of the uniaxial compressive strength $f_{1, \mathrm{c}, \mathrm{m}}$ compared to the compressive strength $f_{\mathrm{cm} \text {, cyl }}$ determined on concrete cylinders ( $h=300 \mathrm{~mm}, d=150 \mathrm{~mm}$ ) and $f_{\text {cm,cube }}$ determined on concrete cubes $(150 \mathrm{~mm})$ are approximately 0.93 and 0.81 , respectively. The uniaxial concrete tensile strength $f_{\text {ctm }}$ is determined by converting the strength from tensile splitting tests with a conversion factor of 1.0 according to fib Model Code 2010 [14]. The experimental values as well as the results derived from mathematical functions of the time-dependent concrete compressive and tensile strengths are shown in Fig. 2.

The modulus of elasticity of the concretes were determined using concrete cylinders prepared with measuring marks and strain gauges for a stress level of $\sigma_{\mathrm{c}}=0.4 \cdot f_{\mathrm{cm}}$ at a concrete age of 276 days and 145 days for the concretes of the test series A and B, respectively. The time-dependent development of the modulus of elasticity can be calculated using Eq. (1).

$$
\begin{aligned}
E_{\mathrm{cm}}(t) & =\left[\frac{f_{1, \mathrm{c}, \mathrm{m}}(t)}{f_{1, \mathrm{c}, \mathrm{m}, 28}}\right]^{0,3} \cdot E_{\mathrm{cm}} \\
& =\left[\frac{f_{1, \mathrm{c}, \mathrm{m}}(t)}{f_{1, \mathrm{c}, \mathrm{m}, 28}}\right]^{0,3} \cdot \alpha_{\mathrm{i}} \cdot 21,500 \cdot\left(\frac{f_{1, \mathrm{c}, \mathrm{m}, 28}}{10}\right) \cdot \alpha_{\mathrm{Ecm}}
\end{aligned}
$$

$\alpha_{\mathrm{i}}-0.8+0.2 \cdot f_{\mathrm{cm}} / 88 ; \alpha_{\mathrm{Ecm}}-1.06$ for concrete grade C $40 / 50$ (test series A) -0.93 for concrete grade C $50 / 60$ (test series $\mathrm{B}$ ); $f_{1, \mathrm{c}, \mathrm{m}}(t), f_{1, \mathrm{c}, \mathrm{m}, 28}$-according to values given in Fig. 2 .

To evaluate the concrete creep coefficients, drill cores $(h \approx 200 \mathrm{~mm}, d \approx 00 \mathrm{~mm}$ ) drilled out from casted cylinders were loaded in a pneumatically controlled test rig at different stress levels over a period of 224 days including a strain measurement. The experimentally determined creep coefficients $\varphi_{\exp }\left(t, t_{0}\right)$ refer to the initial modulus of elasticity at a concrete age of 28 days and are compared with the creep coefficients $\varphi_{\text {calc,EN1992 }}\left(t, t_{0}\right)$ according to [15], see Fig. 3. The coefficients according to [15] are based on simplifications, since it is assumed that the moduli of elasticity are fully correlated with the concrete compressive strength. However, this is not always the case, especially with regard to the large number of 
Table 1 Overview of the investigated test-specimens

\begin{tabular}{|c|c|c|c|c|c|c|c|c|c|c|c|}
\hline Specimen & Load Type & Reinforcement & Concrete & $\begin{array}{l}L_{\mathrm{m}} \text { in } \\
\mathrm{mm}\end{array}$ & $\begin{array}{l}h_{\mathrm{m}} \text { in } \\
\mathrm{mm}\end{array}$ & $\begin{array}{l}b_{\mathrm{m}} \text { in } \\
\mathrm{mm}\end{array}$ & $\begin{array}{l}d_{\mathrm{m}} \text { in } \\
\mathrm{mm}\end{array}$ & $\lambda=a / d_{\mathrm{m}}$ & $\begin{array}{l}\rho_{1} \text { in } \\
\%\end{array}$ & $\begin{array}{l}\omega_{\mathrm{m}} \\
\text { in } \%\end{array}$ & $\begin{array}{l}\text { Age at loading } \\
t_{0} \text { in days }\end{array}$ \\
\hline A-M-C-D1 & Monotonic & CFRP Textile & C $40 / 50$ & 2500 & 105 & 500 & 79.1 & 11.0 & 0.268 & 6.3 & 147 \\
\hline A-M-C-D2 & & & & & & & 83.2 & 10.5 & 0.255 & 5.8 & 307 \\
\hline A-V-C-D1 & & & & 1500 & & & 82.8 & 3.9 & 0.256 & 5.8 & 316 \\
\hline A-V-C-D2 & & & & & & & 84.5 & 3.8 & 0.251 & 5.7 & 312 \\
\hline A-M-S-D1 & & B500 & & 2500 & & & 73.8 & 11.8 & 0.817 & 9.1 & 306 \\
\hline B-M-C-D1 & & CFRP Bars & C 50/60 & 5000 & 200 & 400 & 160.5 & 12.0 & 0.218 & 6.2 & 258 \\
\hline B-M-C-D2 & & & & & & & 157.5 & 12.2 & 0.223 & 6.3 & 253 \\
\hline B-V-C-D1 & & & & 2200 & & & 165.7 & 3.7 & 0.317 & 9.0 & 244 \\
\hline B-V-C-D2 & & & & & & & 168.0 & 3.6 & 0.313 & 8.9 & 254 \\
\hline B-M-S-D1 & & B500 & & 5000 & & & 178.0 & 10.8 & 0.635 & 5.9 & 250 \\
\hline A-M-C-E1 & Cyclic & CFRP Textile & C $40 / 50$ & 2500 & 105 & 500 & 84.0 & 10.4 & 0.253 & 6.7 & 239 \\
\hline A-V-C-E1 & & & & 1500 & & & 79.0 & 4.1 & 0.269 & 7.1 & 273 \\
\hline A-V-C-E2 & & & & & & & 80.0 & 4.0 & 0.265 & 6.9 & 294 \\
\hline A-V-S-E1 & & B500 & & 1500 & & & 80.0 & 4.0 & 0.754 & 8.2 & 313 \\
\hline B-M-C-E1 & & CFRP Bars & C 50/60 & 5000 & 200 & 400 & 163.5 & 11.8 & 0.214 & 6.2 & 410 \\
\hline B-M-C-E2 & & & & & & & 144.0 & 13.4 & 0.243 & 7.2 & 204 \\
\hline B-V-C-E1 & & & & 2200 & & & 161.7 & 3.8 & 0.325 & 9.9 & 115 \\
\hline B-V-C-E2 & & & & & & & 164.8 & 3.7 & 0.319 & 10.0 & 76 \\
\hline B-M-S-E1 & & B500 & & 5000 & & & 175.0 & 11.0 & 0.646 & 5.9 & 183 \\
\hline B-V-S-E1 & & & & 2200 & & & 168.5 & 3.6 & 1.007 & 9.4 & 119 \\
\hline
\end{tabular}

$L_{\mathrm{m}}$ - mean length of the specimen; $h_{\mathrm{m}}$-mean height of the specimen; $b_{\mathrm{m}}$-mean width of the specimen; $d_{\mathrm{m}}-$ mean effective depth of the specimen; $\lambda$-shear slenderness of the specimen; $a$-distance from load introduction point to support; $\rho_{1}-\mathrm{geometric}$ reinforcement ratio; $\omega_{\mathrm{m}}$-mechanical reinforcement ratio (mean values of strength)

possible concrete mixtures and types of aggregate. For this reason, the normative creep coefficients were modified according to the ratio of calculated and empirically obtained modulus of elasticity $E_{\mathrm{c}, \mathrm{i}, 28, \mathrm{EN} 1992} / E_{\mathrm{c}, \mathrm{i}, 28 \text {,exp }}$ after 28 days. In addition to the ratio of experimentally determined and calculated creep coefficients, a grey highlighted scatter range of $\pm 30 \%$ is shown in Fig. 3a, b. The experimentally determined creep coefficients over time are plotted in Fig. 3c, d. For stress levels up to $53 \%$ a good agreement between the experimental data and the prediction model can be seen. For stress levels higher than $70 \%$, for which the prediction model in [15] is not calibrated, the calculated values deviate significantly from the experimental values due to highly non-linear creeping.

\subsection{Reinforcement}

The short-term material properties of the steel and CFRP reinforcement are listed in Table 2. The CFRP textile strands are impregnated with epoxy resin, have a cross-sectional composite area of $8.16 \mathrm{~mm}^{2}$ per strand, a fiber volume ratio of $44 \%$, a mesh size of $38 \mathrm{~mm}$ and a smooth surface. The ribbed CFRP bars are also impregnated with epoxy resin, have a crosssectional composite area of $70.12 \mathrm{~mm}^{2}$ and a fiber volume ratio of $68 \%$. The cross-sectional composite areas are based on an immersion weighing as it is suggested in [16].

While epoxy resins are viscoelastic and show a significant creep behaviour, carbon fibres are comparatively creep resistant up to a temperature of $1200 \mathrm{~K}$ according to [17]. As a result, initial stresses in the composite cross-section that are distributed in accordance with the stiffness ratios of fiber and matrix are progressively transferred to the fibres and the strains 


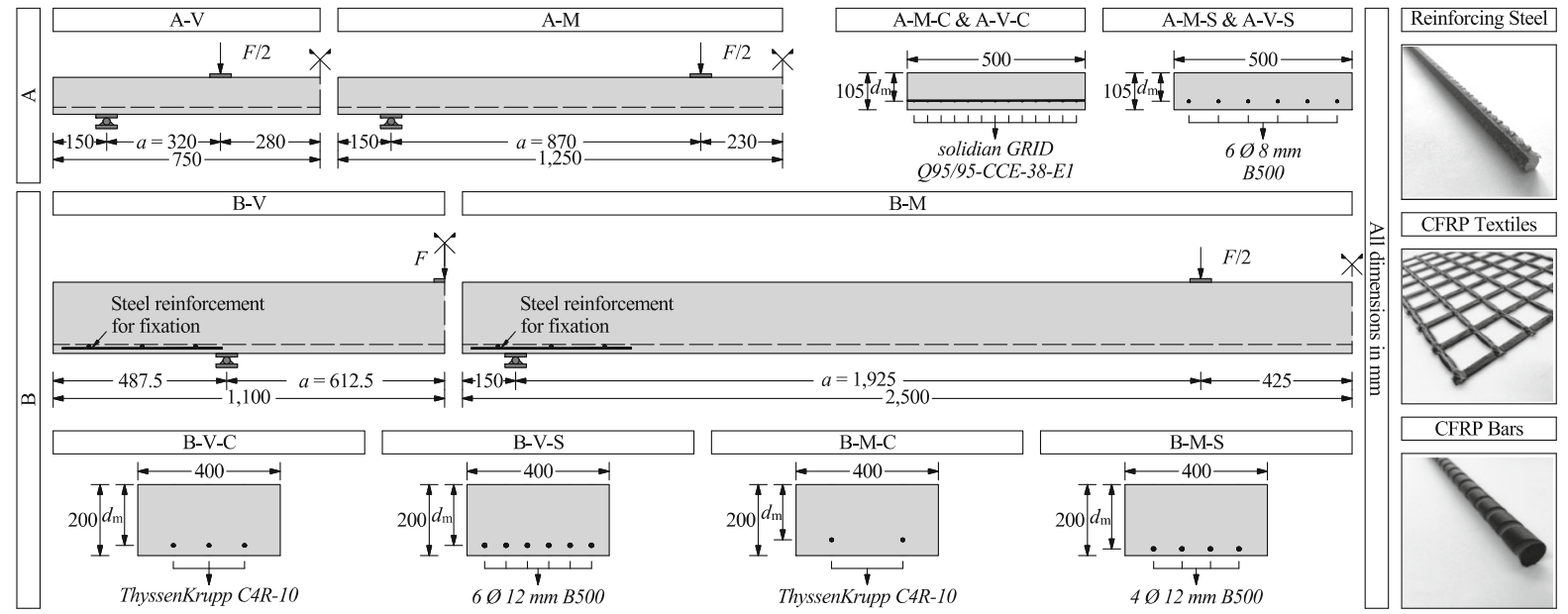

Fig. 1 Cross-sections of the test specimens and test-setups

Fig. 2 Time-dependent concrete compressive and tensile strength

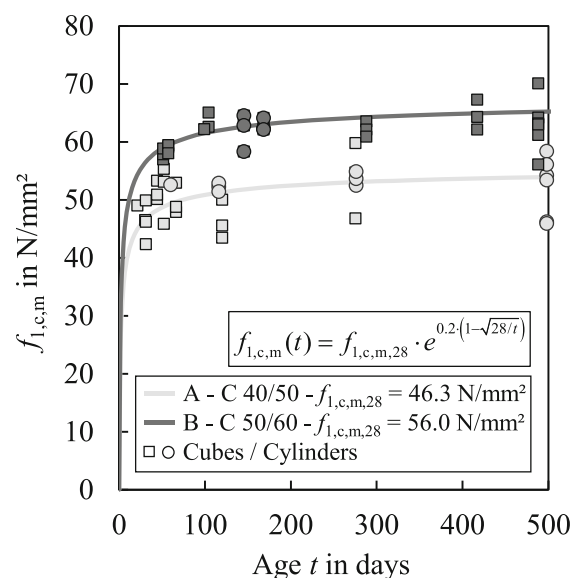

therefore increase [18]. Assuming a mean modulus of elasticity of the epoxy resin of $E_{\mathrm{m}}=3000 \mathrm{MPa}$ (cf. $[19,20])$, the modulus of elasticity of the CFRP textile fibres and the CFRP bar fibres are $E_{\mathrm{f}}=236,777 \mathrm{MPa}$ and $E_{\mathrm{f}}=197,296 \mathrm{MPa}$, respectively. As the fibre contents are known, the ratio of strains at $t=\infty$ and the initial strains can be calculated. For the CFRP reinforcement shown in Table 2, the increase in strain is calculated to be less than $1.6 \%$ of the initial strain and therefore negligible. This FRP internal creep effect can be relevant for materials with fibres of low modulus of elasticity (i. e. glass or basalt) and low fibre content, where the strain increase can reach up to $10 \%$ as it is demonstrated in several experimental investigations [21-27].

Due to the brittle behaviour of FRP reinforcement, the tensile strength is reduced depending on the length under tension and the number of parallel elements. The size effect underlying this phenomenon was analysed in [12, 28, 29]. For the RC members presented in this article, the reduced mean tensile strength of the CFRP textile strands and the CFRP bars can be taken as $f_{\mathrm{tm}}=1189 \mathrm{~N} / \mathrm{mm}^{2}$ and $f_{\mathrm{tm}}=1857 \mathrm{~N} /$ $\mathrm{mm}^{2}$, respectively.

\section{Moment-curvature relations}

To calculate deflections, precise knowledge of the moment-curvature relations of RC cross-sections is required. In general, a trilinear moment-curvature relation as it is shown in Fig. 4 can be assumed $[14,30,31]$. In the uncracked state I up to the cracking moment $M_{\mathrm{cr}}$, the concrete contributes in the 

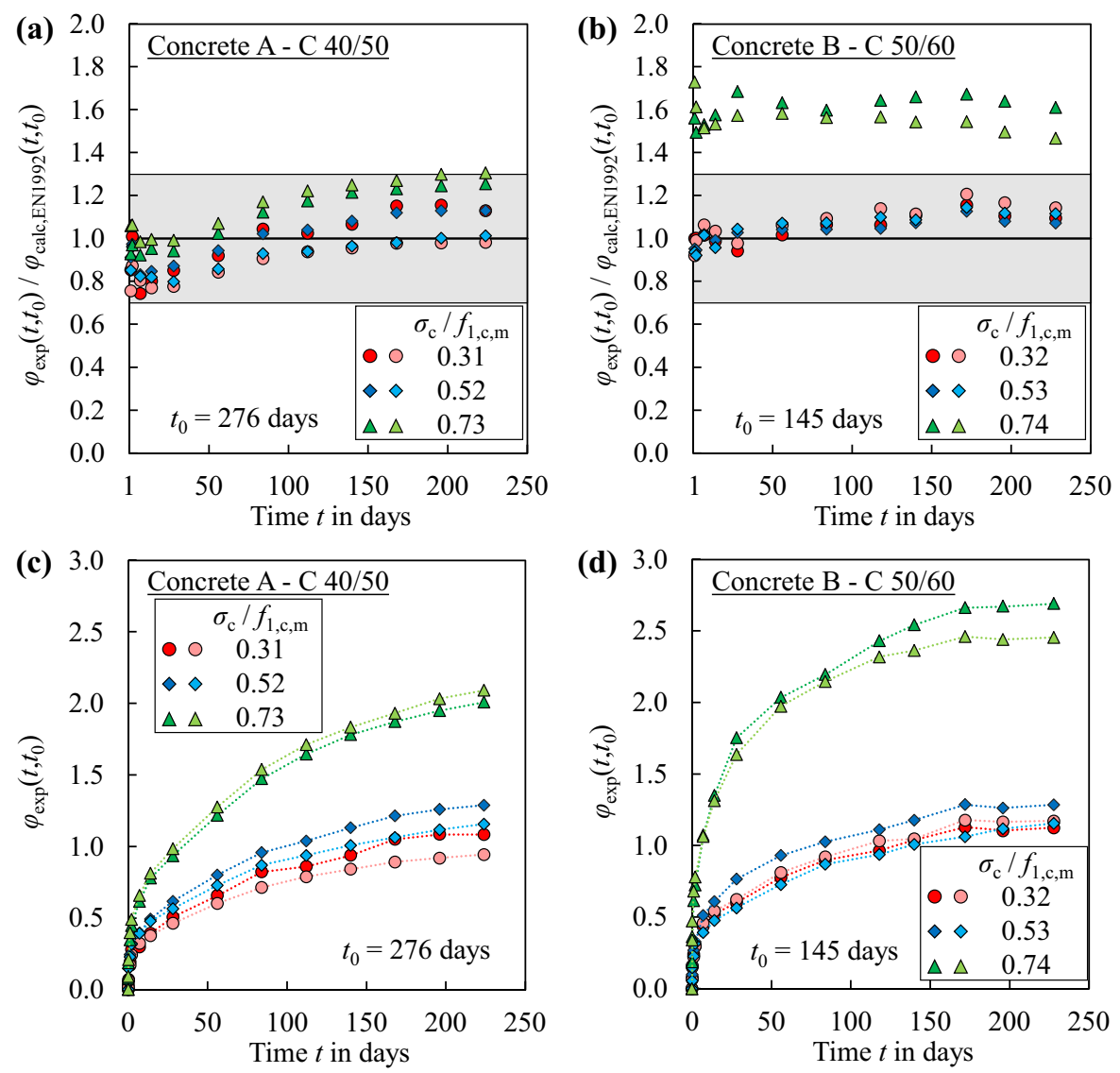

Fig. 3 Comparison of experimental and calculated creep coefficients

Table 2 Material properties of the reinforcement

\begin{tabular}{lllllll}
\hline Reinforcement & Type & $A_{\mathrm{i}}$ in $\mathrm{mm}^{2}$ & $f_{\mathrm{y}, \mathrm{m}}$ in N/mm & $f_{\mathrm{t}, \mathrm{m}}$ in N/mm & $E_{\mathrm{m}}$ in N/mm & $\varepsilon_{\mathrm{u}, \mathrm{m}}$ in \%o \\
\hline Reinforcing steel & B500 $^{\mathrm{a}}$ & Varying & 550 & $\geq 578$ & 200,000 & $\geq 25$ \\
CFRP textile & Solidian GRID Q95/95-CCE-38 & $8.16^{\mathrm{b}}$ & - & $1393^{\mathrm{c}}$ & 105,862 & 13.2 \\
CFRP bars & ThyssenKrupp C4R-10 & $70.12^{\mathrm{b}}$ & - & $1891^{\mathrm{d}}$ & 135,121 & 14.0 \\
\hline
\end{tabular}

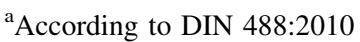

${ }^{\mathrm{b}}$ Average area based on immersion weighing

${ }^{\mathrm{c}}$ Tensile strength tests with a free length of $200 \mathrm{~mm}\left(0^{\circ}\right.$-direction)

${ }^{\mathrm{d}}$ Tensile strength tests with a free length of $400 \mathrm{~mm}$
}

compression as well as the tension zone, leading to a high stiffness and a low curvature. The following crack formation stage usually reaches up to a moment of $1.3 M_{\mathrm{cr}}$, which corresponds to the $95 \%$ quantile of the concrete tensile strength. As can be seen in Fig. 4, the curvatures in the subsequent stabilised cracking stage do not reach the pure state II, in which the concrete tensile strength is completely neglected. This is due to the so-called tension stiffening effect. In the tension zone of a cracked cross-section, the concrete strain equals zero and the tension force is fully carried by the reinforcement. Next to the crack, forces are transferred from the reinforcement to the concrete in the tension zone due to bonding. This reduces the 
mean strains in the reinforcement and therefore also the curvature.

To take the tension stiffening effect into account, the reduced mean curvature $\kappa_{\mathrm{m}}$ can be calculated if the coefficient $\beta_{\mathrm{t}, \mathrm{m}}$ is known. This coefficient is dependent on the bond behaviour of concrete and reinforcement and relates the mean concrete tensile strain $\varepsilon_{\mathrm{cm}}$ to the maximum concrete tensile strain $\varepsilon_{\mathrm{ct}}$. If the ascending branch of the relation between bond stress $\tau$ and slip $s$ is described by Eq. (2), the coefficient $\beta_{\mathrm{t}, \mathrm{m}}$ can be calculated via Eq. (3) according to [30, 32].

$\tau(s)=C \cdot s^{\alpha}$

$\tau(s)$ —bond stress depending on slip $s ; C$-coefficient depending on reinforcement type and concrete strength; $\alpha$-coefficient depending on reinforcement type and bond behaviour

$\beta_{\mathrm{t}, \mathrm{m}}=\frac{S_{\mathrm{r}, \mathrm{m}}}{S_{\mathrm{r}, \max }} \cdot \frac{1+\alpha}{2+\alpha} \cdot \frac{1}{\varphi_{\mathrm{b}}^{\alpha}} \approx \frac{2}{3} \cdot \frac{1+\alpha}{2+\alpha} \cdot \frac{1}{\varphi_{\mathrm{b}}^{\alpha}}$

$s_{\mathrm{r}, \mathrm{m}}$-mean crack spacing; $s_{\mathrm{r}, \max }$-maximum crack spacing; $\varphi_{\mathrm{b}}$-bond creep coefficient; $\varphi_{\mathrm{b}-}$ $=(1+10 t)^{0.08}$ - for steel reinforcement and monotonic long-term loading with $t$ as load duration in $\mathrm{h}$, according to [33]; $\varphi_{\mathrm{b}}=(1+N)^{0.107}$-for steel reinforcement and cyclic long-term loading with $N$ as number of cycles, according to [34].

For typical ribbed steel reinforcement, the coefficient $\alpha$ can be taken as 0.3 according to [30]. If the state of maximum crack spacing $s_{\mathrm{r}, \max }$ is analysed, the coefficient yields to a value of $\beta_{\mathrm{t}}=(1+0.3) /$ $(2+0.3)=0.57$ under short-term loading and is in agreement with the suggestions in $[14,15]$. For the calculation of deflections, however, the mean crack spacing $s_{\mathrm{r}, \mathrm{m}}$ has to be considered and the coefficient $\beta_{\mathrm{t}, \mathrm{m}}$ is reduced with a factor of $s_{\mathrm{r}, \mathrm{m}} / s_{\mathrm{r}, \max }=2 / 3$. Furthermore, the coefficient $\beta_{\mathrm{t}, \mathrm{m}}$ is reduced by the bond creep coefficient $\varphi_{\mathrm{b}}$ due to increasing slip resulting from monotonic or cyclic long-term loading.

To determine the bond properties and the tension stiffening coefficient $\beta_{\mathrm{t}, \mathrm{m}}$, pull-out tests were conducted and reported in [12]. An analysis of the bond stress-slip relation leads to the following coefficients under short-term loading:

Concrete A/CFRP textiles: $\alpha=0.44 \rightarrow \beta_{\mathrm{t}, \mathrm{m}}=0.39$.

Concrete A/Steel: $\alpha=0.40 \rightarrow \beta_{\mathrm{t}, \mathrm{m}}=0.39$.

Concrete B/CFRP bars: $\alpha=0.93 \rightarrow \beta_{\mathrm{t}, \mathrm{m}}=0.44$.

Concrete B/Steel: $\alpha=0.56 \rightarrow \beta_{\mathrm{t}, \mathrm{m}}=0.41$.

For the CFRP bars, it could be observed, that an adhesive bond was contributing to the bond stress-slip relation. After reaching the adhesive bond strength, a high slip with no force increase occurred until the reinforcement ribs interlocked with the surrounding concrete. As the bond law in Eq. (2) has its origin at $\tau(s=0)=0$, the mathematical description compensates this adhesive bond leading to a high coefficient $\alpha$ and therefore to an almost linear regression of the bond stress-slip relation for small values of slip.

\section{RC members under monotonic loading}

\subsection{Test-setup and procedure}

For the analysis of the structural behaviour under monotonic long-term loading with predominant bending, a total of six RC member tests were carried out over a loading period of at least $5000 \mathrm{~h}$. The RC members are loaded with weights, consisting of pre-
Fig. 4 Moment-curvature relation for RC crosssections

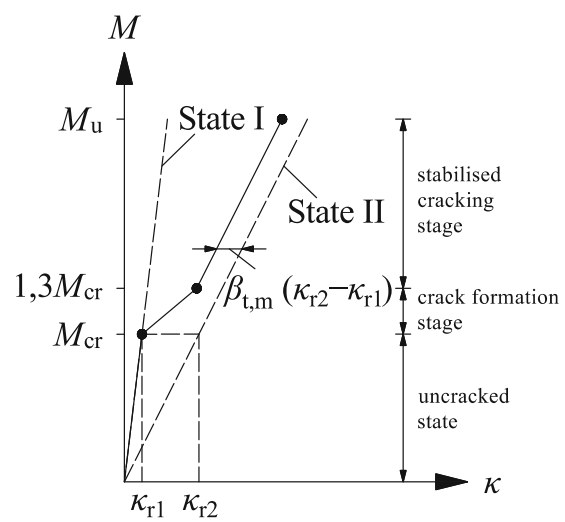

State II: Cracked

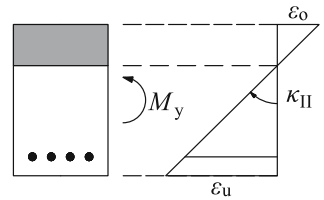

Mean curvature including tension stiffening

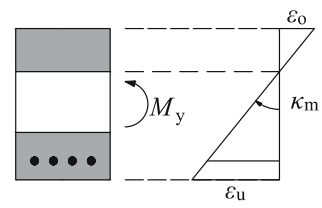


weighed concrete blocks and steel plates. These weights were lifted onto the RC members by means of a crane and slowly lowered. The weights were placed over steel plates and rods on load introduction beams, which were fixed to the RC members with gypsum lime mortar.

Due to the higher loads for the RC members under predominant shear, a test rig was constructed with which the RC members could be loaded. This construction consists of two vertical anchors, which are passed through two crossbars and fixed against the strongfloor with an interposed spring. A hydraulic jack is installed centrally between the two crossbars to apply the load. During the loading process, the hydraulic jack presses against the fixed upper crossbar thus transmitting the load to the RC member via the lower crossbar. During the loading process the actual load applied is determined and monitored by a load cell. At the same time, the high performance compression spring located below the strongfloor is compressed. The stiffnesses of the individual springs were determined in previous tests, so that the current force and the force losses in the system over time can be determined by the deformations of the springs. After reaching the test force (including an overstressing of approx. 5\%), the force is first held by the hydraulic jack and time-dependent force losses due to the decreasing stiffness of the RC members are compensated. After a period of approx. one hour, the lower crossbar is fixed at the top and the hydraulic jack is removed. It was not necessary to readjust the applied force on the RC members, as the force did not drop by more than $10 \%$ during the entire test period of $5000 \mathrm{~h}$.

After the test period of $5000 \mathrm{~h}$ the RC members were transferred to a different test rig and tested regarding their residual load-bearing capacity. The test-setup of the RC members under predominant bending and shear during the period of long-term loading are shown in Fig. 5.

\subsection{Results and discussion}

The relevant results of the experimental investigations on RC members under monotonic long-term loading including the time-dependent deflections are shown in Table 3 and Fig. 6.

To calculate the initial stress level of the RC members under predominant bending, the stresses in the reinforcement $\sigma_{\mathrm{s} / \mathrm{f}}$ are calculated based on an iteration of the cross-section strain plane using the applied loads and the mean effective depth $d_{\mathrm{m}}$ measured after the test period. These stress values are first set in relation to the expected mean value of the reinforcement tensile strength $f_{\mathrm{t}, \mathrm{m}}$. The second stress level given in Table 3 is based on the ultimate residual tensile strength $f_{\mathrm{t}, \mathrm{m} \text {,post }}$, which is recalculated from the load-bearing capacity of the saystem. All CFRP members showed a tension failure of the reinforcement in the residual strength tests. The experimentally determined time-dependent midspan deflections are compared to a numerical calculation showing a good agreement. The coloured areas in Fig. 6 represent a scatter range of the calculation of $\pm 15 \%$. The calculation is done using a numerical approach, which divides the system into 100 elements. For each element, the individual curvature based on the relations in Fig. 4 is calculated. Creeping of the concrete compression zone is taken into account via an effective modulus of elasticity of the concrete $E_{\mathrm{c} \text {,eff }}$ ($\left.t, t_{0}\right)=E_{\mathrm{cm}}(t) /\left[1+\varphi\left(t, t_{0}\right)\right]$, although the creep coefficient is technically referred to the tangent modulus leading to a slightly lower effective modulus of

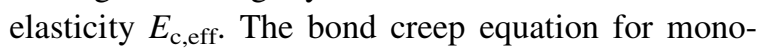
tonic long-term loading given in Eq. (3) had to be adjusted for a better match of the experimental and calculated values. Keeping the same value of $\varphi_{\mathrm{b}}$ for $\mathrm{a}$ period of 50 years, the adjusted equation Eq. (4) was calibrated based on the experimentally derived timedependent deflections.

$\varphi_{\mathrm{b}}\left(t, t_{0}\right)=1+2.4 \cdot\left(\frac{t-t_{0}}{5000+t-t_{0}}\right)^{0.8}$

As it can be seen in the deflections of member B-M-C$\mathrm{D} 2$, there is a sudden increase in deflection at approximately $3200 \mathrm{~h}$. This is due to an additional crack that occurred. The effect of decreasing strength of concrete under sustained loading is well known and has been proven by numerous investigations [35-38]. According to [39], the concrete tensile stength under sustained loading reaches approximately $75 \%$ of the value under short-term loading.

For the interpretation of the results of the RC members under predominant shear, it is necessary to understand that the load is applied differently. When using weights, the load is applied force-controlled. In the case of shear loading, the system is partly displacement-controlled as it is loaded by the fixed 

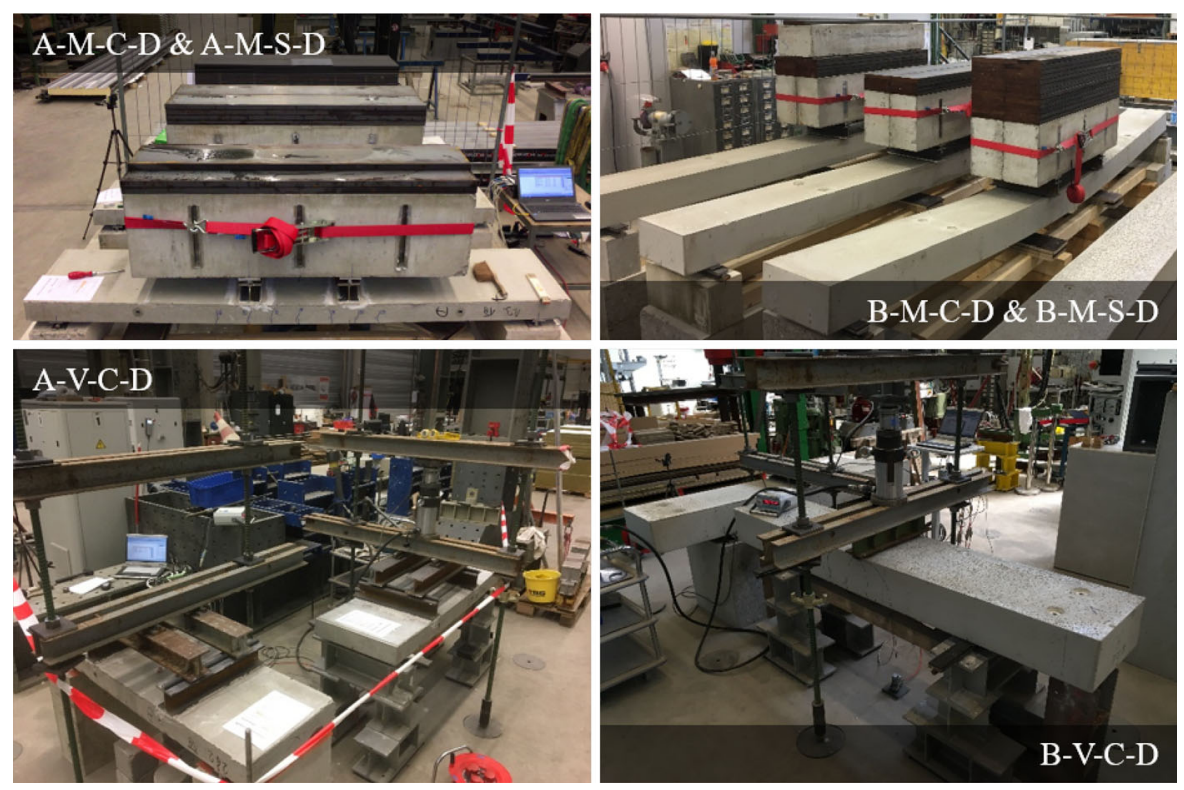

Fig. 5 Test-setup of the RC members under monotonic long-term loading

crossbar described in Sect. 4.1. The irregularities in some parts of the curves in Fig. 6c, d can not be fully explained but are assumed to be caused by unstable measuring at small values of deformation. In Table 3, the shear strength under short-term loading $V_{\text {exp,ref }}$ is based on the experimental investigations reported in [12]. The applied loads are given for different points in time. The first time $t_{0}$ describes the loading sequence in which the load is applied by the hydraulic jack. The second time $t_{1}$ describes the point at which the hydraulic jack is released. The reduction of the load is calculated by the difference of the spring compression. The third time $t_{2}$ marks the end of the load duration of $5000 \mathrm{~h}$. After reaching the end of load duration, the RC members were tested for their residual strength. The members A-V-C-D1 and A-VC-D2 did not fail in shear anymore but in bending, even though the reference tests with the same geometry, reinforcement and shear slenderness showed a typical shear failure. The first reason for this is the increase of concrete strength over time due to hydratation processes as the reference tests under short-term loading were conducted at a concrete age of 54-66 days. At the time of the residual strength tests the concrete age was over 500 days and the concrete strength had increased by approximately $6 \%$. However, the main reason for the increase of the shear strength is attributed to the increase of the concrete compression zone due to creeping of the concrete. For the members A-V-C-D the calculated increase of the concrete compression zone is approximately 34\% allowing for a larger area to transfer shear stresses in the uncracked concrete compression zone. For the member B-V-C-D1, the shear strength is about $4 \%$ lower compared to the values of the reference tests. This is partly attributed to a slightly lower effective depth in the critical cross-section. Both members, B-V-C-D1 and B-V-C-D2, showed a shear failure in the residual strength tests. The increase in strength of member B-V-C-D2 was in the same order of magnitude as for the members A-V-C-D. These experimental results show good agreement with data in the literature, where similar tests were conducted on RC members with steel reinforcement [40].

\section{RC members under cyclic loading}

\subsection{Test-setup and procedure}

Cyclic loading and the resulting crack friction can cause damage to individual outer fibers in the area of the crack due to changing relative displacements and friction-induced increased temperature. Furthermore, the concrete strength decreases due to cyclic loading with increasing number of load cycles, which can lead 


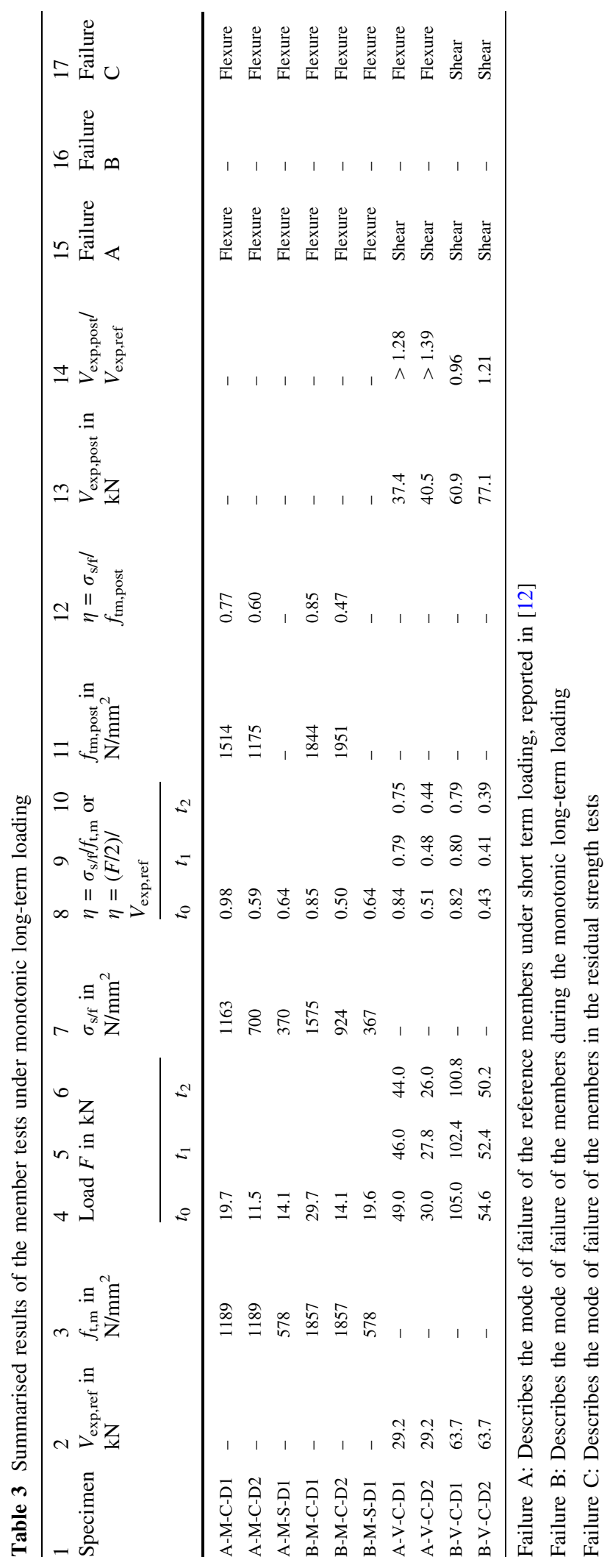


Fig. 6 Time-dependent midspan deflections of the $\mathrm{RC}$ members under monotonic long-term loading
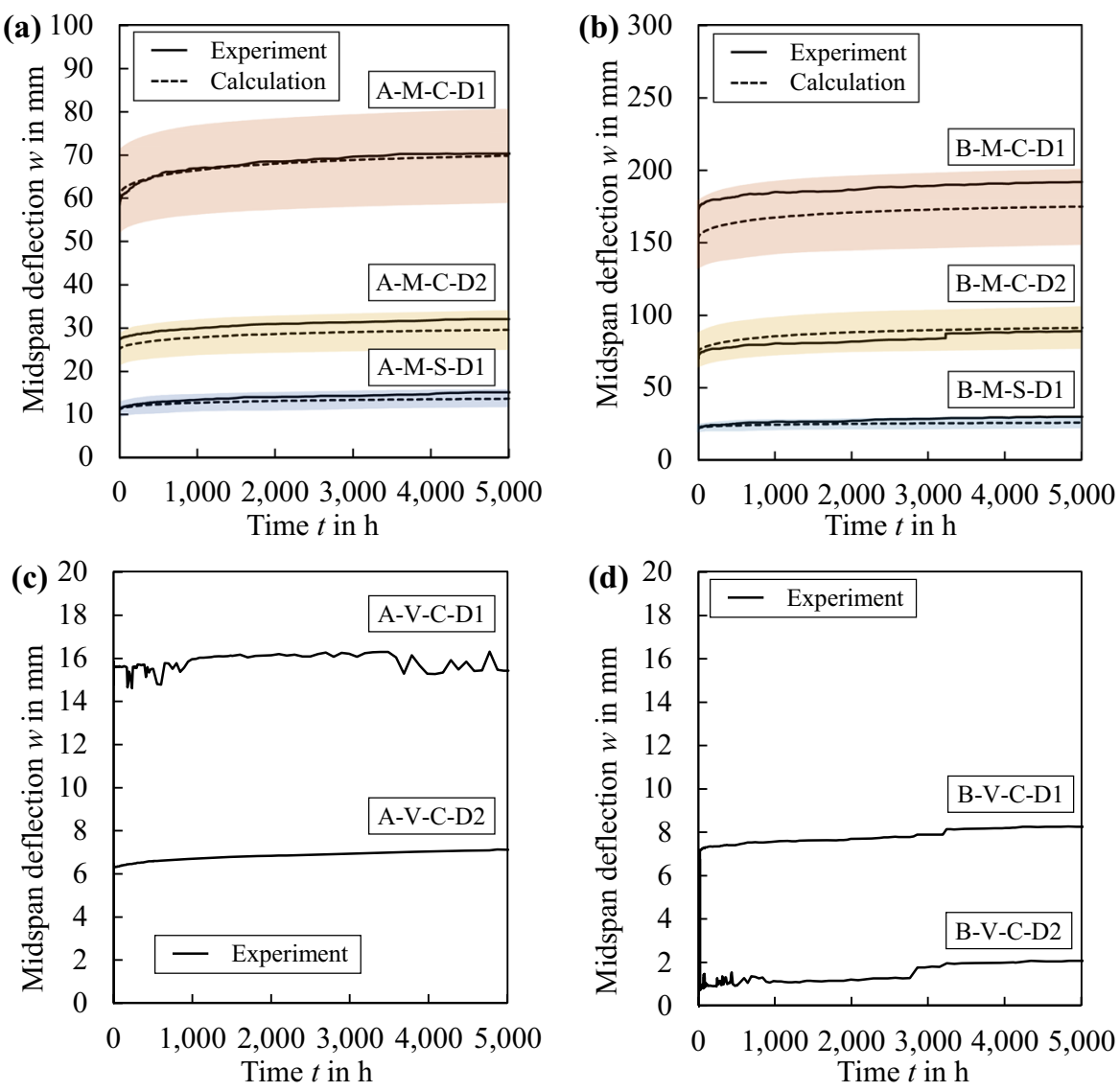

to a critical exceeding of the shear strength. To investigate this influence, a total of 10 member tests were carried out under cyclic long-term loading with a maximum target number of load cycles of $N=10^{6}$ and a load frequency of $f=1 \mathrm{~Hz}$, where geometry and reinforcement were left unchanged compared to the tests under monotonic loading. The maximum and minimum load values are varied leading to different stress ranges in the reinforcement.

At first, the load is increased displacement-controlled until the upper load $F_{\mathrm{u}}$ is reached. Then the members were unloaded completely. After this first load cycle, the load application system was changed into a force-controlled programme. At the beginning of the cyclic loading, the load frequency and the amplitude were increased continuously until the target values were reached. If the members passed the $10^{6}$ cycles, the residual load-bearing capacities were determined in the same test rig. The test-setup of the
$\mathrm{RC}$ members under cyclic long-term loading is shown in Fig. 7.

\subsection{Results and discussion}

The main experimental results of the RC members under cyclic long-term loading are summarised in Table 4.

Columns 4 and 5 show the upper and lower loads $F_{\mathrm{u}}$ and $F_{1}$, leading to the stress values of $\sigma_{\mathrm{s} / \mathrm{f}, \mathrm{u} / \mathrm{l}}$ in the reinforcement axis at the critical cross-section given in columns 6 and 7. For the members that failed due to shear, the load levels in column 11 and 12 are calculated as the upper and lower shear forces related to the shear force capacity of the reference members (column 2). The maximum load at failure measured during the residual strength tests $F_{\text {max,post }}$ is given in Column 14. Column 15 or Failure A describes the mode of failure of the reference members under short- 
term loading. If a failure occurred during the cyclic loading, it is described as Failure B in column 16. If the members resisted the $10^{6}$ load cycles, Failure $\mathrm{C}$ in column 17 describes the mode of failure in the residual strength tests.

The stress ranges and load levels were varied when more than one test per configuration could be conducted. The load level for the first test was chosen higher to target a fatigue failure of the reinforcement in case of predominant bending and shear failure in case of predominant shear. The load level for the second test was chosen lower to simulate a more realistic loading which is relevant for the analysis of deflections.

The test parameters of the four RC members under cyclic long-term loading and predominant bending (A-M-C-E1, B-M-C-E1, B-M-C-E2, B-M-S-E1) can be taken from Table 4 . The stress levels are related to the reduced mean tensile strength of the CFRP reinforcement. The dead weight of the members is also taken into account. The low reinforcement ratios and high load differences lead to large deformation differences between the state of the upper and lower load, which results in high demands on the test rig and the hydraulic jack. Furthermore, the control system and hydraulic circuit react sensitively to the different stiffnesses and load scenarios of the member tests, which makes the optimisation of the control parameters indispensable. Figure 8a, b show the forcedeflection curves and the deflection curves as a function of the number of load cycles of the members A-M-C-E1 and B-M-C-E1. In Fig. 8b, d, the calculated deflections and a hatched scatter range of the calculated deflections of $\pm 15 \%$ are also shown. The calculation is predicting the deflections under the upper load and therefore the top edge of the coloured areas. First, the maximum deflection under the upper load is calculated for the analysis. The additional deflections from cyclic long-term loading are calculated as creep deformations under the middle load $F_{\mathrm{m}}=\left(F_{\mathrm{u}}+F_{1}\right) / 2$. In contrast to the monotonic longterm tests, it could be observed that during the cyclic loading further cracks formed. This is an indication that a reduction of the concrete tensile strength is justified under cyclic loading, see Eq. (5) according to [14].

$f_{\mathrm{ct}, \mathrm{fat}}(N)=f_{\mathrm{ct}} \cdot\left(1-\frac{\log (N)}{12}\right)$

Figure 8a, c show the initial loading process, the cyclic long-term loading and the subsequent determination of the residual load-bearing capacity. All members reach the stabilised cracking stage under the upper load. Regarding the deflections $w$ over the applied number of load cycles $N$, a good agreement between the experimentally and analytically determined values can be found for member A-M-C-E1. The dashed line runs along the upper edge of the red area, which represents the deflections under the upper load. Upon closer examination of the B-M-C-E1 test,
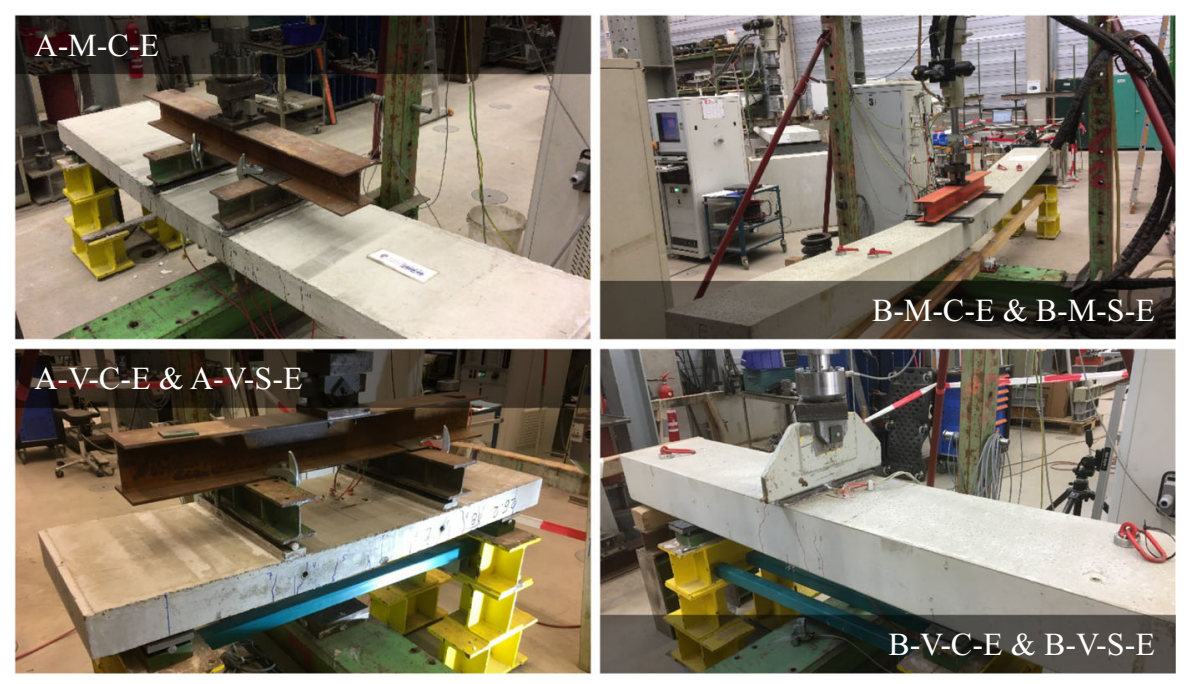

Fig. 7 Test-setup of the RC members under cyclic long-term loading 


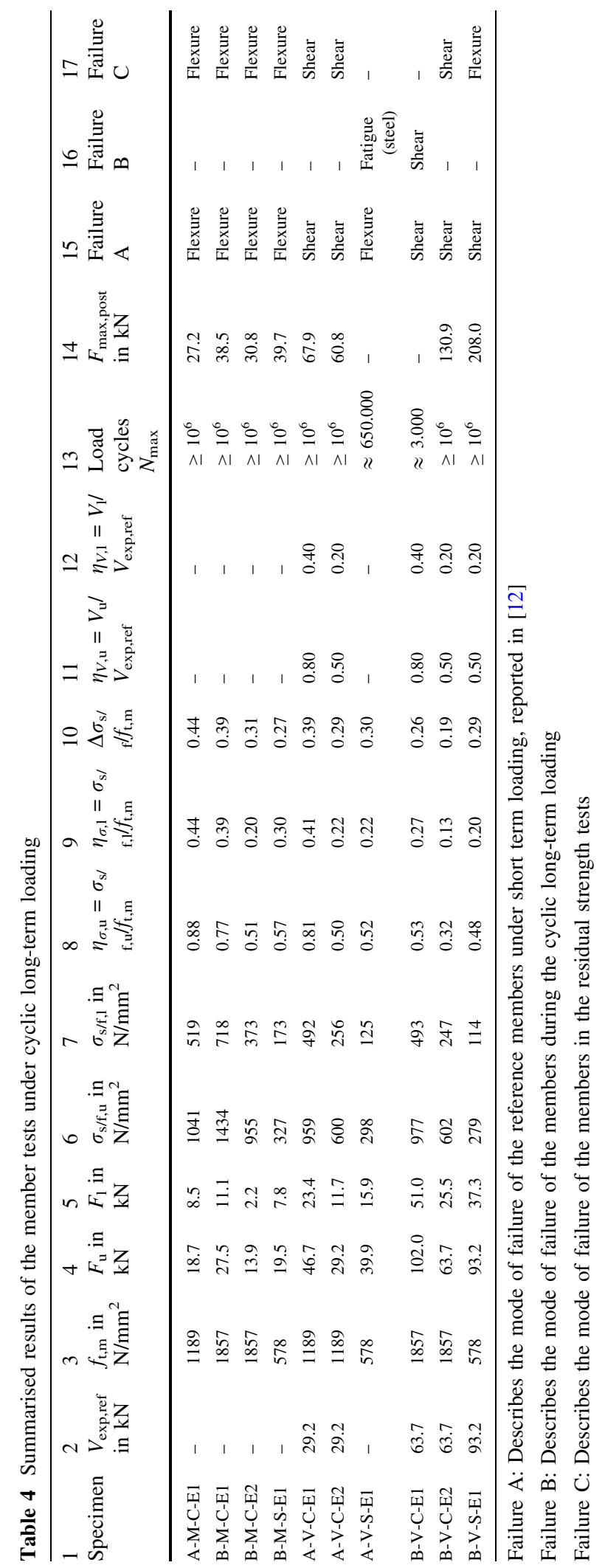


Fig. 8 Results of RC members under cyclic longterm loading (A-M-C-E1, B-M-C-E1, B-M-C-E2, B-M-S-E1)
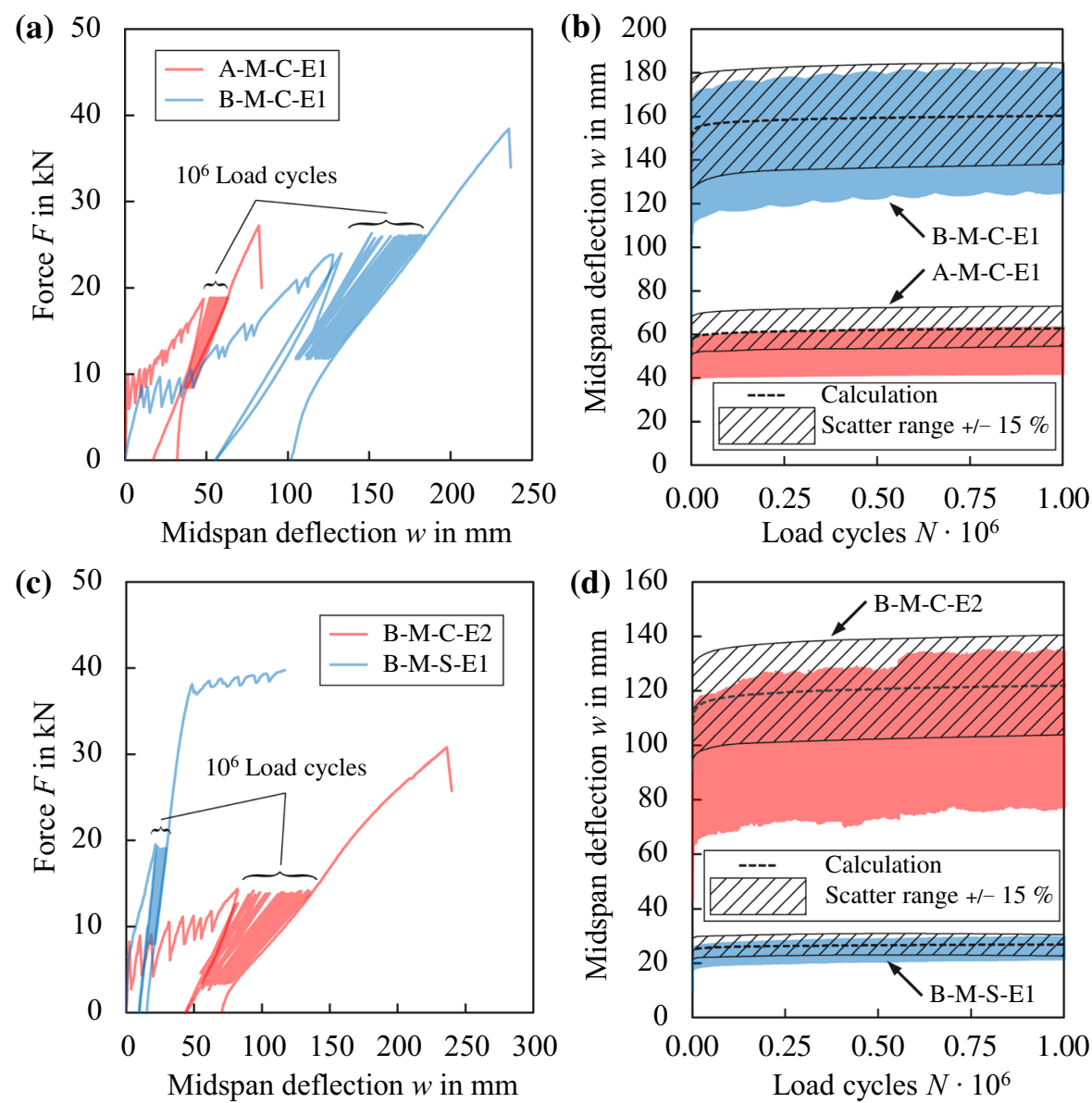

it is noticeable that the measured deflections are higher than the calculated values. This is attributed to the high load level and the fact, that the maximum bond stress between concrete and CFRP reinforcement is exceeded at such high loads. The tension stiffening effect is thus overestimated, which leads to an underestimation of the deflections.

Figure 8c, d also show the results of the two members B-M-C-E2 and B-M-S-E1. As can be seen in Fig. 8d, the initial deflection of B-M-C-E2 can be calculated accurately. In this case, however, the increase in deflections exceeds the predicted value, but remains within the scatter band of $\pm 15 \%$. In principle, a good agreement between the experimental and calculated values can be determined. However, members under cyclic-loading show larger additional deflections, which results from the reduced tensile strength of the concrete as well as from the more severe damage of the bond between concrete and reinforcement.
The test parameters of the six RC members under cyclic long-term loading and predominant shear can be taken from Table 4 .

Figure 9 shows the test results of the four shearmembers that did not fail during the cyclic long-term loading process (A-V-C-E1, A-V-C-E2, B-V-C-E2, B-V-S-E1). In the A-V-C-E2 test, shown in Fig. 9b, a decrease in stiffness at a load cycle number of approximately $N=300,000$ can be seen, which is attributed to the formation of further cracks. The calculation of the deflections shows a good agreement between the experimental and calculated values. In contrast to the residual strength tests of the same members under monotonic loading (A-V-C-D1, A-VC-D2) showing a flexural failure, the members A-V$\mathrm{C}-\mathrm{E} 1$ and A-V-C-E2 showed a shear failure. The determined residual shear force capacity after the cyclic long-term loading period was on average approximately $10 \%$ higher than the reference shear force capacity under short-term loading. 
The aforementioned increase of the height of the concrete compression zone due to creeping thereby increasing the shear capacity of the RC member shows its positive impact under cyclic long-term loading as well as under monotonic long-term loading. On the other hand, the concrete tensile strength is reduced by cyclic loading damage, which results in the observation that the loads cannot be increased to the same extent as under monotonic long term loading.

Figure 9c, d also show the results of the two member tests B-V-C-E2 and B-V-S-E1. No fatigue failure occurred under cyclic loading and the calculation of the deflections shows a good agreement with the experimental data. In both tests, like in the two tests A-V-C-E1 and A-V-C-E2, there was a slight increase in the shear force capacity compared to the reference values under short-term loading. Member B-V-C-E2 failed at a maximum shear force of $V_{\text {max,post }}=65.5 \mathrm{kN}$ which is approximately $3 \%$ more than the reference shear force capacity. At a load of $F_{\text {max,post }}=208.0 \mathrm{kN}$ the longitudinal steel reinforcement in member B-V-S-E1 reached the yield strength, which marks bending failure. Accordingly, the shear force capacity is at least $11.6 \%$ higher than the value of the reference members under short-term loading.

Figure 10 shows the test results of the members A-V-S-E1 and B-V-C-E1, which both failed during the cyclic long-term loading period. As described previously, the reference member of A-V-S-E1 under short-term loading did not fail due to shear but showed a flexural failure (see column 15 in Table 4). Therefore member A-V-S-E1 also did not show a shear failure but a fatigue failure of the steel reinforcement. The absolute stress range in the steel reinforcement is $\Delta \sigma=173 \mathrm{~N} / \mathrm{mm}^{2}$ (column 6 minus column 7 in Table 4). For a number of load cycles of $N=10^{6}$, the characteristic maximum stress range of welded bars and of reinforcing steel meshes according to [15]
Fig. 9 Results of RC members under cyclic longterm loading (A-V-C-E1, A-V-C-E2, B-V-C-E2, B-VS-E1)
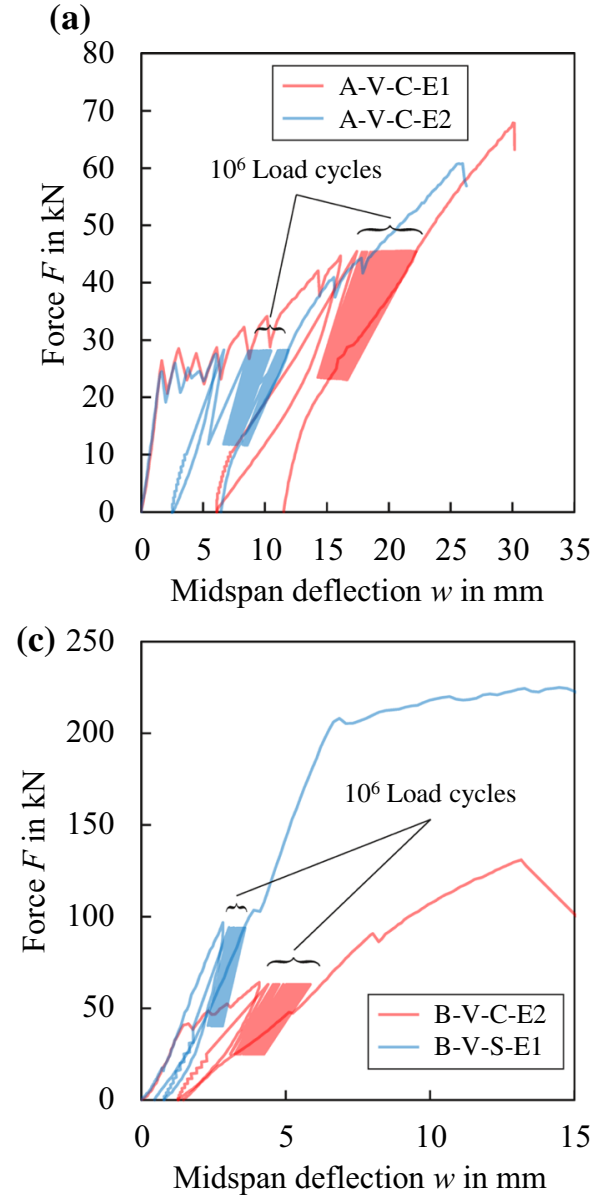
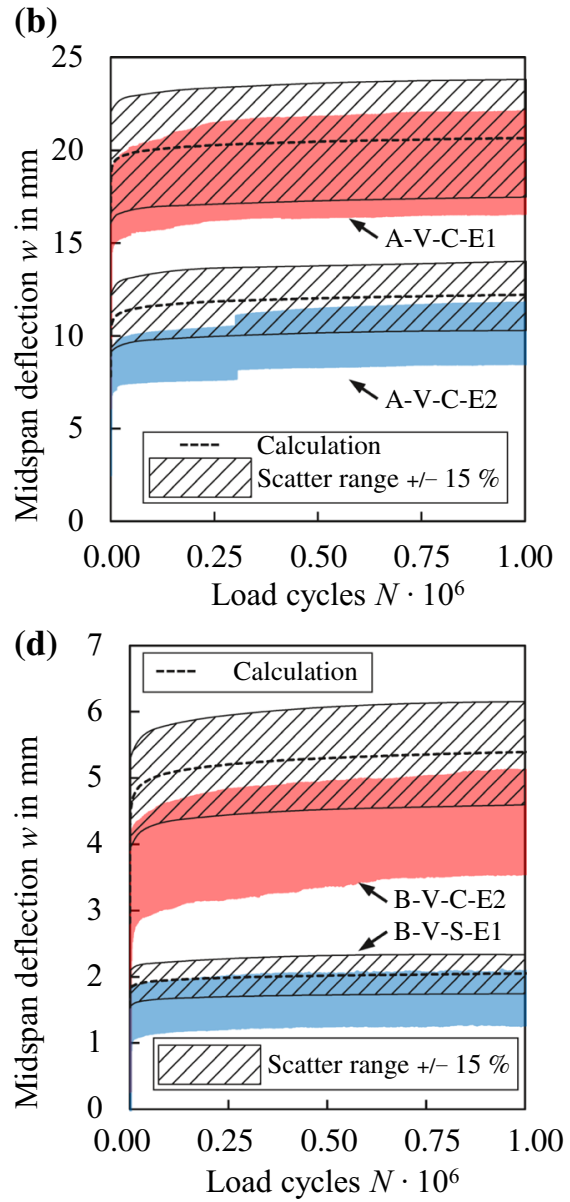
is $\Delta \sigma_{\mathrm{Rsk}}=85 \mathrm{~N} / \mathrm{mm}^{2}$. The actually applied stress range is more than twice this value. At a number of load cycles of $N \approx 570,000$, one of the six bars of the reinforcing steel mesh failed, which can be seen from the significant deflection increase. However, the failure of one of the bars did not lead to failure of the member because the new upper stress reached a value of $\sigma_{\mathrm{u}}=356 \mathrm{~N} / \mathrm{mm}^{2}$ and was therefore still lower than the yield strength. In this state, the stress range was significantly increased to a value of $\Delta \sigma=207 \mathrm{~N} / \mathrm{mm}^{2}$ leading to a tensile fatigue failure of the steel reinforcement at a load cycle number of $N=650,000$.

Test B-V-C-E1 failed at a number of load cycles of approximately $N=3000$. It could already be observed during the first loading stage that the critical shear crack had already propagated into the compression zone. This clearly indicates that the shear force capacity of this member was lower than expected. On the one hand this is due to the large possible scattering of the shear force capacity, on the other hand the effective depth of $d_{\mathrm{m}}=161.7 \mathrm{~mm}$ (see Table 1) of this member B-V-C-E1 was approximately $10 \mathrm{~mm}$ (approximately 6\%) lower than the mean effective depth of the reference members under shortterm loading with a value of $d_{\mathrm{m} \text {,short }}=171.3 \mathrm{~mm}$ reported in [12]. The load level at the beginning of the cyclic loading must therefore be significantly higher than the calculated $80 \%$ (see column 11 in Table 4). After the critical shear crack breaks through the compression zone, the areas near the critical shear crack experience progressive damage, which ultimately leads to a brittle failure of the member. As a secondary shear failure, the CFRP bars are completely sheared off.

\section{Summary and conclusions}

Based on the reference tests under short-term loading reported in [12], the results of the experimental investigations on CFRP RC members under monotonic and cyclic long-term loading are presented in this article.

At first, the material properties of concrete and reinforcement were analysed in detail. For this purpose, experimental investigations were carried out on the time-dependent development of the concrete compressive and tensile strength. The creep parameters of the concretes were determined by experimental investigations and compared with prediction models. It turned out that the model in [15] provides accurate results at stress levels of $30 \%$ and $50 \%$. At high stress levels, where non-linear creep is dominant, the creep deformations are underestimated.

To investigate the structural behaviour of CFRP RC members under monotonic long-term loading, 10 large-scaled tests with varying test parameters were conducted. None of the members failed within the long-term loading period of $5000 \mathrm{~h}$. The member tests were recalculated with the help of the previously explained input parameters with regard to the timedependent deflections, taking into account creeping of the concrete compression zone and the decreasing tension stiffening effect. A good agreement between the calculated and experimental results was observed.
Fig. 10 Results of RC members under cyclic longterm loading (A-V-S-E1, B-V-C-E1)
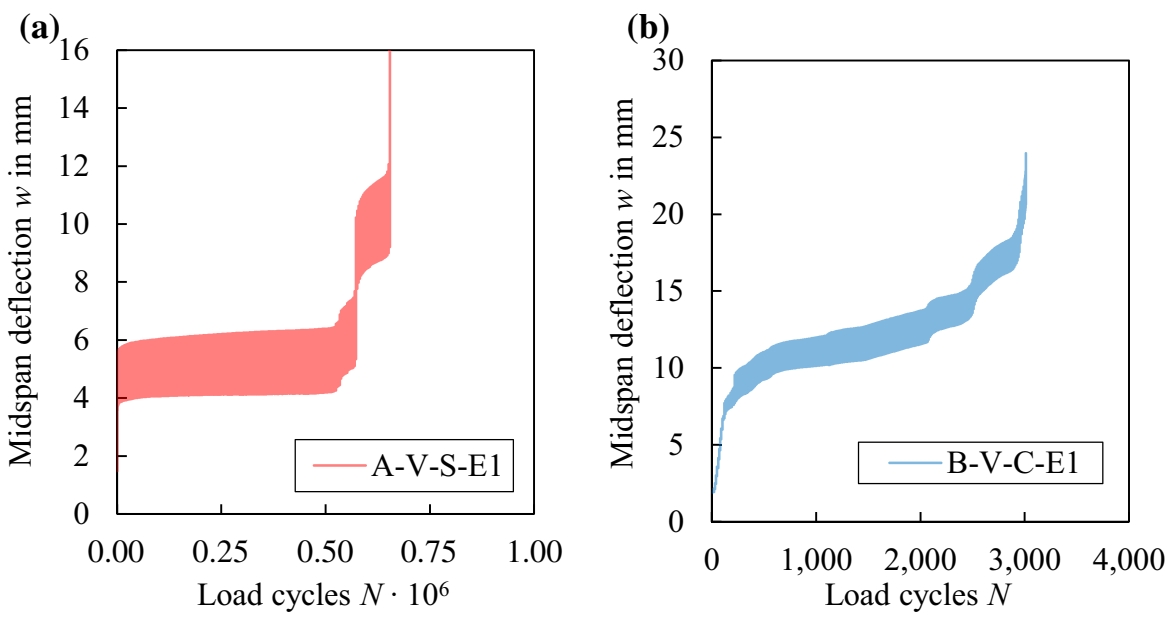
After the long-term loading period, the residual load capacities were determined. No significant loss of load-bearing capacity due to the applied preload was detected. The determination of the residual loadbearing capacity showed that the shear capacity increased significantly compared to the load capacity under short-term loading reported in [12]. These results correspond with the shear tests carried out on RC members with steel reinforcement in the literature, where an increase of the shear capacity was also observed. This aspect can be attributed in particular to the creep-induced increase of the height of the concrete compression zone as well as the posthardening of the concrete.

For the investigation of the load-bearing capacity and deflection behaviour of the CFRP RC members under cyclic long-term loading, a total of 10 largescaled tests with a maximum load cycle number of $N=10^{6}$ were carried out. Despite the partly high stresses and stress ranges, no fatigue failure of the CFRP reinforcement could be observed. In two cases, members failed prematurely under cyclic loading. Member B-V-C-E1 with a maximum shear force load level of approximately $80 \%$ (related to the average value of the shear force capacity of the reference tests) failed at a load cycle number of approximately $N=3000$. However, it was observed that the member showed a critical crack pattern during the initial loading process, where the critical shear crack already propagated into the compression zone. Since the shear capacity is subjected to strong scattering, the load level was probably higher than the calculated $80 \%$. Member A-V-S-E1, which was reinforced with conventional reinforcing steel, failed after a number of load cycles of approximately $N=650,000$ due to material fatigue of the reinforcing steel. The stress range was more than twice the permissible characteristic stress range for reinforcing steel meshes according to [15]. The members that did not fail during the cyclic long-term loading process were tested for their residual load-bearing capacity. Again, no general load-bearing capacity decrease could be determined. The members under cyclic long-term loading and predominant shear, similar to the members under monotonic long-term loading, tended to an increase of their shear force capacity.

In conclusion, it can be stated that concrete members with CFRP reinforcement have a high resistance to monotonic and cyclic loading. If there is no failure during long-term loading, an increase in the load-bearing capacity can be expected, especially in the case of predominant shear. The existing models for the calculation of deflections in RC structures are applicable to concrete members with CFRP reinforcement if the specific material and bond parameters are known. For FRP reinforcement with a low ratio of fibre to matrix stiffness, the FRP reinforcement tends to creep. This effect has to be taken into account when calculating deflections.

Acknowledgements The authors would like to thank the German Federal Ministry of Education and Research for the support and funding of the research project "C3-V2.1-Longterm behaviour of Carbon Concrete", the company solidian for providing the textile reinforcement and the company Goldbeck for the production and supply of the concrete members.

Funding Open Access funding enabled and organized by Projekt DEAL.

\section{Declaration}

Conflict of interest We declare no conflict of interests.

Open Access This article is licensed under a Creative Commons Attribution 4.0 International License, which permits use, sharing, adaptation, distribution and reproduction in any medium or format, as long as you give appropriate credit to the original author(s) and the source, provide a link to the Creative Commons licence, and indicate if changes were made. The images or other third party material in this article are included in the article's Creative Commons licence, unless indicated otherwise in a credit line to the material. If material is not included in the article's Creative Commons licence and your intended use is not permitted by statutory regulation or exceeds the permitted use, you will need to obtain permission directly from the copyright holder. To view a copy of this licence, visit http://creativecommons.org/licenses/by/4.0/.

\section{References}

1. Zintel M, Angst U, Keßler S, Gehlen C (2014) Epoxidharzbeschichtete Bewehrung - Neue Erkenntnisse nach zwei Jahrzehnten Praxiserfahrung. Beton- und Stahlbetonbau 109:3-14

2. Hofmann S, Proske T, Graubner C-A (2020) Verbundverhalten besandeter basaltfaserverstärkter Kunststoffbewehrung. Beton- und Stahlbetonbau 115(7):514-522

3. Hofmann S, Tran NL, Proske T, Graubner C-A (2020) Cracking behavior of basalt fibre reinforced polymer-reinforced concrete: an approach for the determination of crack spacing and crack width. Struct Concr 21(5):2178-2190

4. Wagner J, Spelter A, Hegger J, Curbach M (2020) Ermüdungsverhalten von Carbonbeton unter Zugschwellbelastung. Beton- und Stahlbetonbau 115:1-10 
5. Spelter A, Bergmann S, Bielak J, Hegger J (2019) Longterm durability of carbon-reinforced concrete: an overview and experimental investigations. Appl Sci MDPI 9:1651

6. Schumann A, May M, Curbach M (2018) Carbonstäbe im Bauwesen. Beton- und Stahlbetonbau 113(12):868-876

7. Schumann A, May M, Schladitz F, Scheerer S, Curbach M (2020) Carbonstäbe im Bauwesen. Beton- und Stahlbetonbau 115(12):962-971

8. Bielak J, Schmidt M, Hegger J, Jesse F (2020) Structural behavior of large-scale I-beams with combined textile and CFRP reinforcement. Appl Sci 10(13):4625

9. Preinstorfer P, Pinzek A, Kollegger J (2020) Modellierung des Verankerungsverhaltens getränkter textiler Bewehrungen. Beton- und Stahlbetonbau 115(9):720-730

10. Mousa S, Mohamed HM, Benmokrane B, Nanni A (2020) Flexural behavior of long-span square reinforced concrete members with uniformly distributed fiber-reinforced polymer bars. ACI Struct J 117(4):66

11. Lieboldt M, Tietze M, Schladitz F (2018) $C^{3}$-Projekt Erfolgreiche Partnerschaft für Innovation im Bauwesen. Bauingenieur 7/8:265-73

12. El Ghadioui R, Proske T, Tran NL, Graubner C-A (2020) Structural behaviour of CFRP reinforced concrete members under bending and shear loads. Mater Struct 53(3):3

13. Grübl P, Weigler H, Karl S (2001) Beton - Arten, Herstellung und Eigenschaften, 2nd edn. Ernst \& Sohn, Berlin

14. fib Model Code 2010 (2013) CEB-FIP fib Model Code 2010 for concrete structures: Fédération internationale du béton(fib Model Code 2010).Ernst \& Sohn, Berlin

15. DIN EN 1992-1-1 (2011) Eurocode 2: Bemessung und Konstruktion von Stahlbeton- und Spannbetontragwerken Teil 1-1: Allgemeine Bemessungsregeln und Regeln für den Hochbau; Deutsche Fassung EN 1992-1-1:2004 + AC:2010, in Verbindung mit Änderung A1 (2015): DIN Deutsches Institut für Normung e. V.(DIN EN 1992-1-1). Beuth Verlag, Berlin

16. ASTM D7205/7205M-06 (2006) Standard test method for tensile properties of fiber reinforced polymer matrix composite bars: ASTM International(ASTM D7205/7205M06). ASTM International, West Conshohocken

17. Hull D, Clyne TW (1996) An introduction to composite materials, 2nd edn. Cambridge University Press, Cambridge

18. fib Bulletin 40 (2007) FRP reinforcement in RC structures: Fédération internationale du béton(fib Bulletin 40). International Federation for Structural Concrete, Lausanne

19. Ehrenstein GW (2006) Faserverbund-Kunststoffe: Werkstoffe - Verarbeitung - Eigenschaften, 2nd edn. Carl Hanser Verlag GmbH \& Co. KG, München

20. Schürmann H (2007) Konstruieren mit Faser-KunststoffVerbunden, 2nd edn. Springer, Berlin

21. Gaona FA (2003) Characterization of design parameters for fiber reinforced polymer composite reinforced concrete systems. Texas A \& M University, Texas, Dissertation

22. Youssef T, El-Gamal S, El-Salakawy E, Benmokrane B (2008) Experimental results of sustained load (creep) tests on FRP reinforcing bars for concrete structures. In: Proceedings of the 37th CSCE annual conference, Quebec City, Canada

23. Sayed-Ahmed M, Hajimiragha B, Hajimiragha B, Mohamed K, Benmokrane B (2017) Creep rupture and creep behaviour of newly third generation GFRP bars subjected to sustained loads. In: Proceedings of the 5th international conference on durability of FRP composites for construction and rehabilitation of structures

24. Nkurunziza G, Benmokrane B, Debaiky AS, Masmoudi R (2005) Effect of sustained load and environment on longterm tensile properties of glass fiber-reinforced polymer reinforcing bars. ACI Struct J 102:615-621

25. Wang X, Shi J, Liu J, Yang L, Wu Z (2014) Creep behavior of basalt fiber reinforced polymer tendons for prestressing application. Mater Des 59:558-564

26. Yang D, Zhang J, Song S, Zhou F, Wang C (2018) Experimental investigation on the creep property of carbon fiber reinforced polymer tendons under high stress levels. Mater MDPI 11:2273

27. Ascione F, Berardi VP, Feo L, Giordano A (2008) An experimental study on the long-term behavior of CFRP pultruded laminates suitable to concrete structures rehabilitation. Compos B 39:1147-50

28. Rempel S, Ricker M (2017) Ermittlung der Materialkennwerte für die Bemessung von textilbewehrten Bauteilen. Bauingenieur 92:280-288

29. Rempel S (2018) Zur Zuverlässigkeit der Bemessung von biegebeanspruchten Betonbauteilen mit textiler Bewehrung. Aachen: Rheinisch-Westfälische Technische Hochschule Aachen, Lehrstuhl und Institut für Massivbau, Dissertation

30. König G, Tue NV (1996) Grundlagen und Bemessungshilfen für die Rißbreitenbeschränkung im Stahlbeton und Spannbeton: Deutscher Ausschuss für Stahlbeton - DAfStb Heft 466. Beuth Verlag, Berlin

31. Zilch K, Zehetmaier G (2010) Bemessung im konstruktiven Betonbau. Springer, Berlin

32. Tue N, König G (1992) Calculating the mean bond and steel stress in reinforced and prestressed concrete members. Darmstadt Concrete 6:66

33. Franke L (1976) Einfluß der Belastungsdauer auf das Verbundverhalten von Stahl in Beton (Verbundkriechen): Deutscher Ausschuss für Stahlbeton - DAfStb Heft 268. Ernst \& Sohn, Berlin

34. Rehm G, Eligehausen R (1977) Einfluss einer nicht ruhenden Belastung auf das Verbundverhalten von Rippenstählen. Betonwerk- und Fertigteiltechnik 6:295-299

35. Rüsch H (1960) Researches toward a general flexural theory for structural concrete. ACI J 57:1-28

36. Rüsch H, Sell R, Rasch C, Grasser E, Hummel A, Wesche K et al (1968) Festigkeit und Verformung von unbewehrtem Beton unter konstanter Dauerlast: Deutscher Ausschuss für Stahlbeton - DAfStb Heft 198. Ernst \& Sohn, Berlin

37. Wittmann F, Zaitsev J (1974) Verformung und Bruchvorgang poröser Baustoffe bei kurzzeitiger Belastung und Dauerlast: Deutscher Ausschuss für Stahlbeton - DAfStb Heft 232. Ernst \& Sohn, Berlin

38. Nechvatal D, Stöckl S, Kupfer H (1994) Kriechen, Rückkriechen und Dauerstandfestigkeit von Beton bei unterschiedlichem Feuchtegehalt und Verwendung von Portlandzement bzw. Portlandkalksteinzement: Deutscher Ausschuss für Stahlbeton - DAfStb Heft 442. Ernst \& Sohn, Berlin

39. Kordina K, Schubert L, Troitzsch U (2000) Kriechen von Beton unter Zugbeanspruchung: Deutscher Ausschuss für Stahlbeton - DAfStb Heft 498. Ernst \& Sohn, Berlin 
40. Sarkhosh R, Walraven J, Den Uijl J (2015) Shear-critical reinforced concrete beams under sustained loading-Part I: experiments. HERON 60(3):181-206
Publisher's Note Springer Nature remains neutral with regard to jurisdictional claims in published maps and institutional affiliations. 